Journal of Sustainable Development of Transport and Logistics

journal home page: https://jsdtl.sciview.net

Esmer, S. (2020). Effects of Belt and Road Initiative on port selection. Journal of Sustainable

Development of Transport and Logistics, 5(1), 115-123. doi:10.14254/jsdtl.2020.5-1.11.

\title{
Effects of Belt and Road Initiative on port selection
}

\section{Soner Esmer}

Iskenderun Technical University, Iskenderun, Hatay, Turkey;

Dokuz Eyul University, İzmir, Turkey

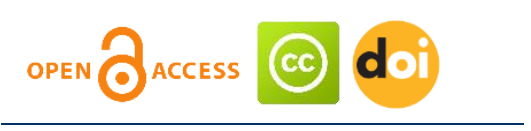

Article history:

Received: March 09, 2020

1st Revision: March 21, 2020

Accepted: April 28, 2020

DOI:

10.14254/jsdtl.2020.5-1.11
Abstract: Purpose: Belt and Road Initiative (BRI) was announced by China in 2013. In the initiative, railway lines are operated (Belt), and sea transportation is continuing with sea routes (Road) between China and Europe. The geographical scope of the initiative covering the Chinese-European route is increasing day by day. The purpose of this study is to identify the strategies that container terminals in sea routes need to consider to achieve sustainable competitive advantage. Methodology: To achieve the goal, I focused on the criteria that container ship operators considered in port selection as the main user of the container terminals. In the study, a qualitative research process was followed, and data was collected through semi-structured interviews. Results: It is seen that the bilateral agreements between the countries where the ports are located have gained importance especially with China and the other countries involving the initiative. Moreover, it has been determined that the connections with the railway infrastructure will create a competitive advantage. The contribution: The container terminals located on the route have not only enough with classical advantages such as location, equipment, and infrastructure to achieve sustainable competitive advantage. The new criteria found in the study are the areas where the port cannot directly intervene individually. However, the port operator may negotiate with the relevant parties.

Keywords: Belt and Road Initiative, container, terminal, port selection criteria.

\section{Introduction}

In today's world, the effects of Industry 4.0 technologies are not only felt in the production sector but also our daily lives. With the widespread use of industrial robots, which is an Industry 4.0 technology, in production, dependence on the workforce will decrease. This is a threat to countries in the Far East, such as China, which is far from the consumer market, attracts global production and investment based on cheap labour in the future.

Corresponding author: Soner Esmer

E-mail: soneresmer@gmail.com

This open access article is distributed under a Creative Commons Attribution (CC-BY) 4.0 license. 
As a result of the slowdown in the local economy, China faced a decrease in trade both globally and between its internal regions (Timmer et al., 2016). Besides, the possibility of promoting local production with Industry 4.0 technologies in developed countries has pushed China, which is currently the production base of the world, to alternative policies such as the structuring of various foreign trade policies and making many international agreements by the Chinese government to ensure the continuity of production. One of these initiatives is the revival of the ancient Silk Road under the BRI (Mark, 2014).

With BRI initiative, access to the European market by road was called "Belt", while access by sea was called "Road". With this initiative, China has revived the historical Silk Road alternative, especially railroad routes, to access the European market, on the other hand, the necessary importance has been given to the sea leg with strategic moves. Although the BRI is similar to the Marshall Plan of America in some aspects, it is a different structure in terms of its basic structure. BRI is not an international aid initiative.

The basic information about BRI is as follows (Huang, 2016; Du \& Zhang, 2018; Yu, 2017):

- First, the BRI is an important move for China to make its economic development sustainable.

- China intends to transfer its vast experience to international markets, assume important responsibilities and manage the international economy by serving the world production for years. China especially wants to develop the infrastructure of undeveloped and developing countries with its experience. It strives to reshape the global economic system through the BRI and the Asian Infrastructure Investment Bank (AIIB) financing.

- While infrastructure development is one of the key elements in the BRI, the initiative is within a much more complex scope. The initiative includes political dialogues, the interconnectivity of infrastructures, barrier-free trade, financial support, and expert exchange programs.

- Finally, the BRI offers important opportunities in creating new economic foundations and in developing new policies for economic development. However, this initiative also has significant risks, such as managing geopolitical risks, coordinating international policies and ensuring financial sustainability in transnational projects.

As of 2019, the number of countries and international enterprises included in BRI has reached 125 in the 5 years since the announcement of the project, and the total volume of trade exceeded 6 trillion dollars (XINHUANET, 2019).

Fig. 1 shows the main routes of the BRI. The corridors on the land route are the New Silk Road Economic Belt, the China-Pakistan economic corridor and the Bangladesh-China-India-Myanmar economic corridor.

The study focuses on the Maritime Silk Road. The sea silk road within the scope of BRI is deployed on the classic Far Eastern-European maritime trade route shown in Fig. 1. Important ports on this route are Fuzhou, Shanghai, Hanoi, Singapore, Jakarta, Nairobi and Piraeus (Athens).

The BRI has affected the maritime sector as well as many other sectors (Schinas \& Westarp, 2017). China strengthened it with significant investments in container ship lines operated by a public subsidiary, and also made many port investments on the route. However, alternative ship line and port operations also operate on this important maritime route of the world, in other words, it competes with China. The main motivation of this study is based on this competition. In this study, the literature on port competition and port selection criteria was examined, and then, a qualitative research process was applied within the scope of the BRI. 
Figure 1: Logistic networks in BRI

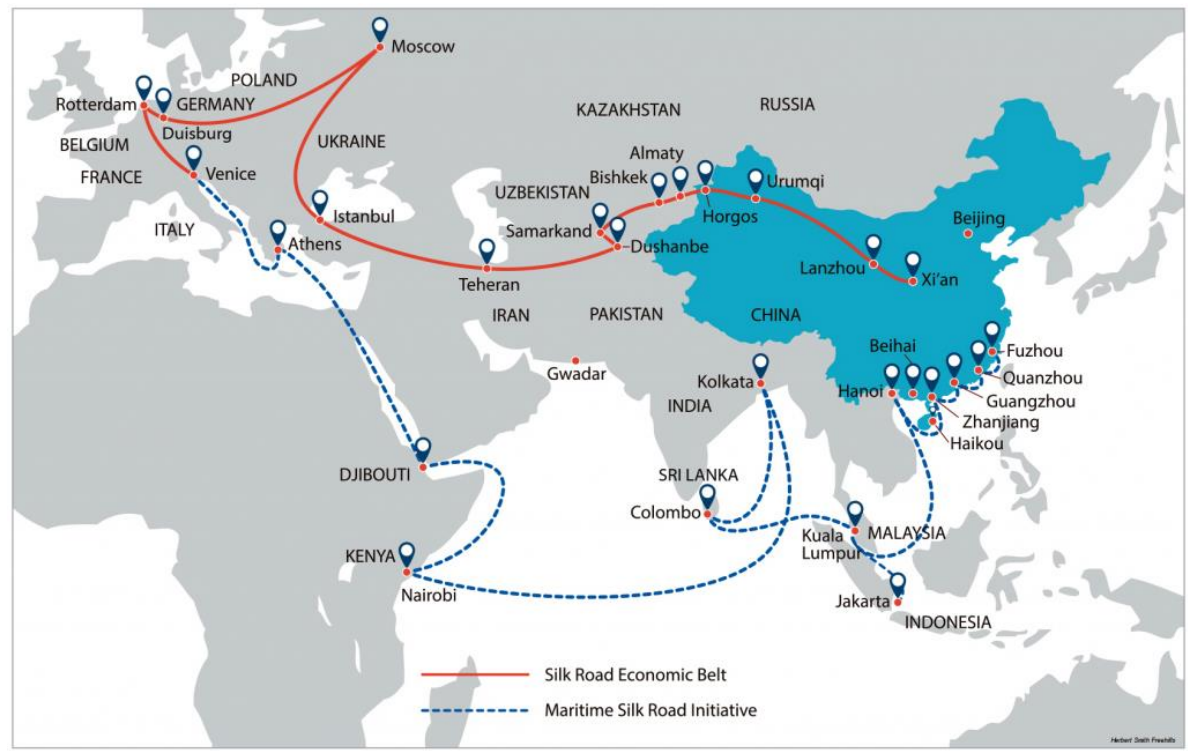

Source: Future Directions International, 2020

http://www.futuredirections.org.au/publication/making-sense-of-five-years-of-chinas-belt-and-roadinitiative/bri-map/

\section{Port competition and port selection criteria}

Growing global trade volume in the 1990s especially increased the importance of container transportation and container terminal management. From a broader perspective, port competition can be divided into five main groups (Gross, 1990):

1. Competition between whole ranges of ports or coastlines,

2. Competition between ports in different countries,

3. Competition between individual ports in the same country,

4. Competition between the operators or providers of facilities within the same port,

5. Competition between different modes of transport.

When the studies on port competition are examined in the literature, it is seen that these studies generally focus on port selection criteria. Many factors determine the competitive advantage of ports. These factors include up-to-date equipment, the port's expansion possibilities, the contracts with important container lines, the efficiency of the feeder routes, price tariffs and operational efficiency (Song \& Yeo, 2015).

In addition to these criteria, it is seen that criteria such as corporate social responsibility have been used in recent years (Yuen et al., 2017). In terms of terminal type, it is seen that port competition and port selection studies are generally oriented towards container transportation. However, in recent years, studies on dry bulk transportation have also started to take its place in the literature (Balci et al., 2018). A summary of these studies is presented in Table 1. Although the port selection of different parties in these studies is done with different methodologies, these studies are mainly oriented to the container transport sector.

As can be seen in Table 1, the studies on port competition are based on choosing the most suitable port among more than one port considering the specific criteria of the port users. Today, the port selection of port users has become much more complicated due to changing the role of ports in the international supply chain and logistics over time. Besides, port users demand more complex and multidimensional services from the ports instead of basic services such as cargo handling and storage. Besides, as in the focus of this study, international initiatives such as BRI have taken the port competition to a different dimension. 
Table 1: Port selection criteria in the literature

\begin{tabular}{|c|c|}
\hline Criteria & Author(s) \\
\hline Annual working hours & Tang et al., 2008 \\
\hline Accessibility and ease of operation & Tang et al., 2008; Yeo et al., 2008; Yeo et al., 2014 \\
\hline Damage and loss performance & $\begin{array}{l}\text { Balci et al., 2018, Langen, 2007; Murphy and Daley 1994; } \\
\text { Tongzon } 2009\end{array}$ \\
\hline Cargo volume & $\begin{array}{l}\text { Murphy and Daley, 1994; Song and Yeo, 2004; Tang et al., 2008; } \\
\text { Tiwari et al., 2003; Tongzon and Sawant, 2007, }\end{array}$ \\
\hline Ability to solve problems & Murphy and Daley, 1994 \\
\hline Eligibility to receive the cargo & Murphy and Daley, 1994 \\
\hline Customer orientation & Balci et al., 2018; Langen, 2007 \\
\hline Water depth & Tang et al., 2008; Tiwari et al., 2003 \\
\hline Productivity & Tongzon and Sawant, 2007; Tongzon, 2009 \\
\hline Port equipment & Langen, 2007; Murphy and Daley, 1994 \\
\hline Hinterland connections & Langen, 2007; Tang et al., 2008; Yeo et al., 2008; Yeo et al., 2014 \\
\hline Information services & Langen, 2007; Murphy and Daley, 1994 \\
\hline Logistics costs & Nir et al., 2003; Yeo et al., 2008; Yeo et al., 2014 \\
\hline Number of docks and cranes & Balci et al., 2018, Tiwari et al., 2003 \\
\hline Number of routes served & Nir et al., 2003; Tiwari et al., 2003 \\
\hline Quick response to customer needs & Balci et al., 2018, Tongzon, 2009 \\
\hline Personal communication at the port & Langen, 2007 \\
\hline Port administration and management & Guy and Urli 2006; Lirn et al., 2004 \\
\hline Port tariff & $\begin{array}{l}\text { Balci et al., 2018, Guy and Urli, 2006; Lirn et al., 2004; Tang et } \\
\text { al., 2008; Tiwari et al., 2003; Tongzon and Sawant, 2007; } \\
\text { Tongzon, } 2009\end{array}$ \\
\hline Infrastructure and superstructure of the port & $\begin{array}{l}\text { Guy and Urli, 2006; Lirn et al., 2004; Tongzon and Sawant, } \\
\text { 2007; Tongzon, 2009 }\end{array}$ \\
\hline Port location & $\begin{array}{l}\text { Balci et al., 2018, Alonso and Soriano, 2009; Guy and Urli, 2006; } \\
\text { Langen, 2007; Lirn et al., 2004; Malchow and Kanafani, 2001; } \\
\text { Nir et al., 2003; Song and Yeo, 2004; Tongzon and Sawant, } \\
\text { 2007; Tongzon, } 2009\end{array}$ \\
\hline Port services & Tongzon and Sawant, 2007; Yeo et al., 2008; Yeo et al., 2014 \\
\hline Being a regional hub & Yeo et al., 2008; Yeo et al., 2014 \\
\hline Frequency of ships & $\begin{array}{l}\text { Langen, 2007; Malchow and Kanafani, 2001; Nir et al., 2003; } \\
\text { Tongzon, } 2009\end{array}$ \\
\hline Ship service time & Tang et al., 2008 \\
\hline Handling capabilities for special loads & Murphy and Daley, 1994 \\
\hline
\end{tabular}

\section{Methodology}

Port selection criteria are the factors that port users consider when choosing a port. Therefore, for the ports to attract customers and compete with other ports, they need to focus on these criteria. This research includes the initial results of more extensive research. In the study, a qualitative research process was followed, and data was collected through semi-structured interviews. Semi-structured interview technique is one of the best methods for the in-depth examination of the subject in qualitative research (Wilson, 2011). Questions were asked to the experts of the subject with the semistructured interview form and the criteria were asked to be evaluated within the scope of BRI. Thus, port selection criteria were achieved within the scope of BRI.

\subsection{Sample}

Two main elements of maritime transport are the transportation of cargo in the seas and the handling of cargo in the ports (Rodrigue, 2010). In other words, ship management and port management are the two main branches of maritime transportation. Container line operators, a form of ship management companies in container transportation, are vital for international trade and global supply chains (Balci and Cetin, 2017). Since the main customers of the container terminals are container lines, the questions are addressed directly to them. The experts whose ideas were consulted by the scope of the study were selected from the container lines listed in Table 2 . These container lines 
ranked among the top 10 in the world. These container ship operators represent $81.7 \%$ of the total global container capacity as of May 2020. Participants in the study consist of 21 middle and senior managers working in these enterprises.

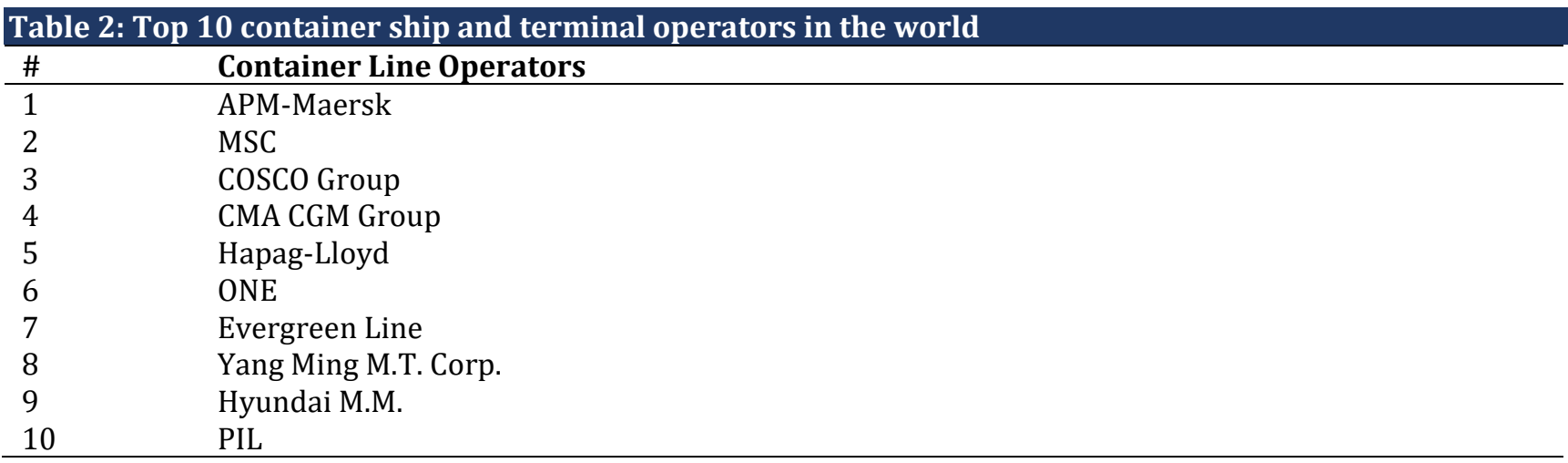

Source: Alphaliner, 2019. https://alphaliner.axsmarine.com/PublicTop100/ (11.01.2020)

The data collection process took place between December 2019 and January 2020. Generally, the way of reaching the head office from local agencies or representatives has been followed, managers from middle and high level from each business and who are mainly interested in operation activities have been reached, each business has contributed to working with two or three participants (Table 3).

\begin{tabular}{|c|c|c|c|}
\hline $\begin{array}{l}\text { Pseudonym of the } \\
\text { lines }\end{array}$ & \# of interviewees & Position of interviewees & $\begin{array}{c}\text { Represented by a direct or } \\
\text { third-party agent }\end{array}$ \\
\hline A & 2 & $\begin{array}{l}\text { Branch manager, Export } \\
\text { manager }\end{array}$ & Direct \\
\hline B & 2 & $\begin{array}{l}\text { Agency manager, } \\
\text { Import manager }\end{array}$ & Third-Party \\
\hline C & 3 & $\begin{array}{l}\text { Sales executive, Import } \\
\text { manager, Export manager }\end{array}$ & Direct \\
\hline $\mathrm{D}$ & 2 & $\begin{array}{l}\text { Agency manager, Line } \\
\text { manager }\end{array}$ & Third-Party \\
\hline E & 2 & $\begin{array}{l}\text { Line manager, Sales } \\
\text { manager }\end{array}$ & Direct \\
\hline $\mathrm{F}$ & 2 & $\begin{array}{l}\text { Agency manager, Export } \\
\text { manager }\end{array}$ & Third-Party \\
\hline G & 2 & $\begin{array}{l}\text { Branch manager, Export } \\
\text { manager }\end{array}$ & Third-Party \\
\hline $\mathrm{H}$ & 2 & $\begin{array}{l}\text { Branch manager, Import } \\
\text { manger }\end{array}$ & Direct \\
\hline I & 2 & $\begin{array}{l}\text { Agency manager, Line } \\
\text { manager }\end{array}$ & Third-Party \\
\hline $\mathrm{J}$ & 2 & $\begin{array}{l}\text { Agency manager, Import } \\
\text { manager }\end{array}$ & Third-Party \\
\hline
\end{tabular}

Judgemental sampling, which is one of the non-probability sampling methods, the samples are not chosen by chance, the presence of certain features are sought in the samples to be selected. For this reason, in the non-probability sample selection techniques, everyone in the universe has no equal chance of being selected for sampling (De Vaus, 1990). The interviewees were selected through the judgemental sampling method so that the selection of individuals with the capacity to answer the research questions was secured. 


\subsection{Qualitative research process: a semi-structured interview}

Boddy (2016) stated that 12 interviews are enough to reach theoretical saturation in qualitative research. On the other hand, Bryman (2008) stated that, if new theories can no longer be developed through interviews, this means that sufficient interviews have been reached. Two-stage semistructured interviews were conducted with 21 participants who filled out the form. In the first stage of the interview, the participants were shown the classical port selection criteria in the literature and asked to choose what they consider important among these criteria. In the second stage, participants were asked whether an additional criterion is required for port selection within the scope of the BRI. Most of the interviews were conducted electronically.

\section{Research findings}

As a result of the qualitative research process, a total of 16 criteria were obtained. These 16 criteria and their brief explanations are as follows:

1. Physical capability of the port: It refers to the physical infrastructures for the operation such as the docks/piers of the port, the depth of the water, the width of the port basin, the manoeuvring room and the approach channel.

2. Port equipment: It refers to all equipment used in cargo handling and ship manoeuvres.

3. Cargo handling speed: It refers to the operation speed related to unloading the cargo from the ship and loading the cargo to the ship, especially at the dock.

4. Cargo handling costs: Refers to costs in the entire transportation process, such as port tariffs, freights, intermediate handling.

5. Current local and transhipment cargo volume of the port: The amount of cargo currently handled by the port.

6. Storage facilities of the port: It is the storage facility and capacity of the port.

7. The location of the port on the BRI routes: It is the location where the port is located on the sea routes of BRI.

8. The operator of the port: It refers to the local or global structuring of port operators (Global Terminal Operators etc.).

9. Hinterland (transportation) connections of the port: It means the port's land and railway transportation connections.

10. Connections to the Belt side of the BRI: It refers to the accessibility of the port's railway connections to the BRI routes.

11. Customer relations of the port: It expresses the enthusiasm of the port's customer representatives.

12. Damage/loss performance of the port: It refers to the damage and loss load rate that occurs within the port.

13. Bilateral relations of the host country with China (Bilateral agreements): Refers to the extent of the agreements and cooperation between the governments.

14. Trade relations of the host country with China: It expresses the size of the business relations between the enterprises in the country where the port is located and the enterprises in China.

15. The transit cargo legislation of the host country: Refers to the simplicity or complexity of the transit cargo legislation in the country where the port is located.

16. The level of integration (vertical/horizontal) of the port: It refers to the level of integration of the port with other ports or with other elements of the supply chain, such as ship lines, logistics centres, dry ports or logistics service providers.

The framework defined for these mentioned criteria is also demonstrated in Fig. 2. 


\section{Figure 2: A proposed framework}

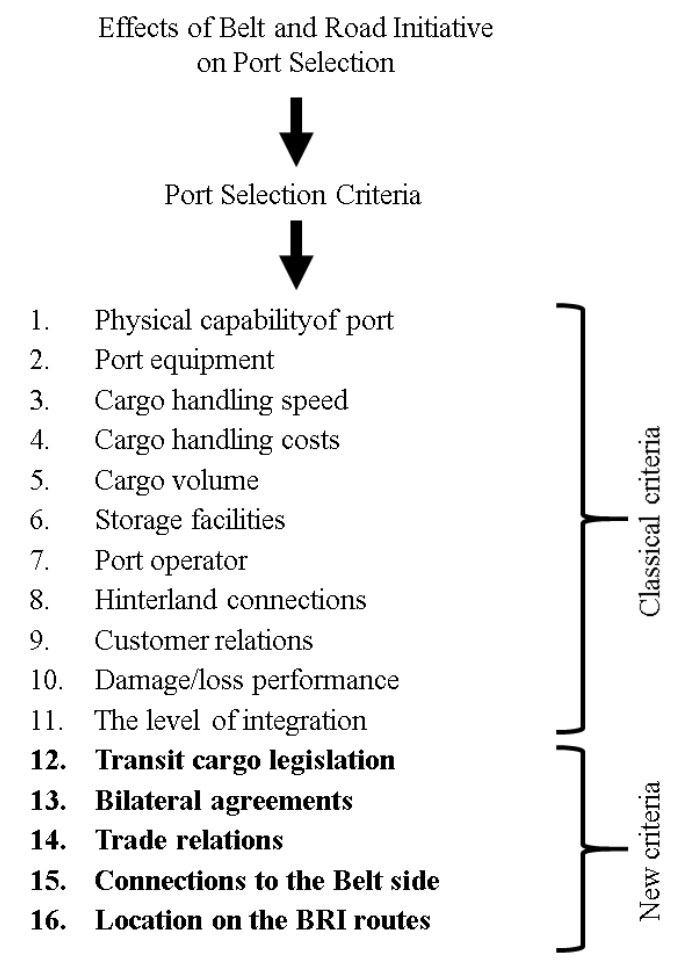

The criteria are selected or recommended at least once by the participants. Due to the nature of the qualitative research, all proposed or selected criteria are taken into account. The criteria do not have any prioritization among themselves, and the results are given in random order. Discussions on the findings are included in the conclusion section.

\section{Conclusion}

Competition between container terminals, which are the basic transportation infrastructure of container transportation, has been continuing at many levels since the past. Additional dimensions are added to the competition environment every day. A new perspective and level of competition for container transportation have emerged on a global scale, such as BRI.

In this study, a qualitative research process has followed to determine criteria to achieve sustainable competitive advantage. Since they are the main customers of the container terminals, the questions are addressed directly to the representative of container line operators. Although most of the obtained criteria are similar to the literature, new criteria have also proposed by the participants.

Criteria such as the physical facilities of the port, port tariff, the equipment owned by the port, cargo handling speed, current cargo volume, storage facilities, transportation connections to the hinterland, customer relations and loss/damage rates are already in the literature. On the other hand, proposing new criteria within the scope of BRI led to the results expected from the study. The original findings of the research include the presence of railway connections to the "Belt" leg of the BRI, the commercial trade level of the countries between China and the host country, location on the BRI routes, transit cargo legislation and bilateral agreements between China and Port State.

Container terminals must make strategic decisions if they want to maintain their competitive advantage and achieve sustainable competitive advantage. By their very nature, strategic decisions have long-term consequences for businesses. Some of the criteria determined in this research consist of the macro environment and some of them are microenvironment (business environment) factors. The location of the port, the hinterland connections, the transit cargo legislation of the country in which the port is located, and bilateral agreements between the port country and other BRI countries are areas where the port cannot directly intervene individually. However, the port operator may negotiate with the relevant public institutions on the increase of bilateral agreements, improvement of hinterland connections or improvements in transit legislation through its associations and nongovernmental organizations. On the other hand, it will be under its control that the port company 
takes strategic steps to improve its relations with all parties with whom it has commercial relations. At this point, the subject of which criteria determined in this research will be prioritized is another research subject.

The study is an exploratory research form and has a preparation feature for the next stage. In this respect, this study is the first stage of a comprehensive study. It is aimed to determine the order of importance of obtained variables with a multi-criteria decision-making methodology applied to the port service demand and supply sides. Thus, the variables that the ports on the route should give the most important within the scope of BRI can be determined.

\section{Citation information}

Esmer, S. (2020). Effects of Belt and Road Initiative on port selection. Journal of Sustainable Development of Transport and Logistics, 5(1), 115-123. doi:10.14254/jsdtl.2020.5-1.11

\section{References}

Alonso, L. G., \& Soriano, J. S. (2009). Port selection from a hinterland perspective. Maritime Economics and Logistics, 11(3), 260-269.

Alphaliner. (2019). Alphaliner Information - Top 100 League. Retrieved 23.11.2019 from https://alphaliner.axsmarine.com/PublicTop100/.

Balci, G, Cetin, I.B., \& Esmer, S. (2018). An evaluation of competition and selection criteria between dry bulk terminals in Izmir. Journal of Transport Geography, 69, 294-304.

Balci, G., \& Cetin, I. B. (2017). Market segmentation in container shipping services: a qualitative study. Management Research Review, 40(10), 1100-1116.

de Langen, P. W. (2007). Port competition and selection in contestable hinterlands: the case of Austria. European Journal of Transport and Infrastructure Research, 7(1), 1-14.

de Vaus, D. A. (1990). Surveys in social research (2nd ed., vol. 11). London: Unwin Hyman.

$\mathrm{Du}$, J., \& Zhang, Y. (2018). Does one belt one road initiative promote Chinese overseas direct investment?. China Economic Review, 47, 189-205.

Future Directions International. (2020). BRI Map. Retrieved from http://www.futuredirections.org.au/publication/making-sense-of-five-years-of-chinas-belt-androad-initiative/bri-map/

Goss, R. O. (1990). Economic policies and seaports: Strategies for port authorities. Maritime Policy \& Management, 17(4), 273-287.

Guy, E., \& Urli, B. (2006). Port selection and multicriteria analysis: An application to the Montreal-New York Alternative. Maritime Economics \& Logistics, 8(2), 169-186.

Huang, Y. (2016). Understanding China's Belt \& Road initiative: motivation, framework and assessment. China Economic Review, 40, 314-321.

Kim, A. R. (2016). A study on competitiveness analysis of ports in Korea and China by Entropy weight TOPSIS. The Asian Journal of Shipping and Logistics, 32(4), 187-194.

Malchow, M., \& Kanafani, A. (2001). A disaggregate analysis of factors influencing port selection. Maritime Policy \& Management, 28(3), 265-277.

Mark, J. J. (2014). Silk Road. Ancient History Encyclopedia. Retrieved 25.11 .2019 from http://www.ancient.eu/silk_road/.

Murphy, P. R., \& Daley, J. M. (1994). A comparative analysis of port selection factors. Transportation Journal, 34(1), 15-21.

Nir, A. S., Lin, K., \& Liang, G. S. (2003). Port choice behaviour - from the perspective of the shipper. Maritime Policy \& Management, 30(2), 165-173.

Schinas, O., \& von Westarp, A. G. (2017). Assessing the impact of the maritime silk road. Journal of Ocean Engineering and Science, 2(3), 186-195.

Sheu, J. B., \& Kundu, T. (2018). Forecasting time-varying logistics distribution flows in the One BeltOne Road strategic context. Transportation Research Part E: Logistics and Transportation Review, 117, 5-22.

Song, D. W., \& Yeo, G. T. (2015). A Competitive Analysis of Chinese Container Ports Using the Analytic Hierarchy Process. In Port Management (pp. 339-359). Palgrave Macmillan, London. 
Song, D. W., \& Yeo, K. T. (2004). A competitive analysis of Chinese container ports using the analytic hierarchy process. Maritime Economics \& Logistics, 6(1), 34-52.

Tang, L. C., Low, J. M., \& Lam, S. W. (2011). Understanding port choice behaviour - a network perspective. Networks and Spatial Economics, 11(1), 65-82.

Tımmer, H., Bussolo, M., Gould, D.M., Letelier, R.A., Nguyen, T.C., Panterov, G.L., Shaw, W., Ushakova, E., Burns, A., Izvorskı, I.V., Pigato, M.A., \& Sanchez, C. (2016). The impact of China on Europe and Central Asia. Europe and Central Asia economic update. Washington, D.C.: World Bank Group. ISBN (Electronic): 978-1-4648-0912-5.

Tiwari, P., Itoh, H., \& Doi, M. (2003). Shippers' port and carrier selection behaviour in China: a discrete choice analysis. Maritime Economics \& Logistics, 5(1), 23-39.

Tongzon, J. L. (2009). Port choice and freight forwarders. Transportation Research Part E: Logistics and Transportation Review, 45(1), 186-195.

Tongzon, J. L., \& Sawant, L. (2007). Port choice in a competitive environment: from the shipping lines' perspective. Applied Economics, 39(4), 477-492.

XINHUANET. (2019). China's goods trade with B\&R countries reaches over 6 trillion dollars. Retrieved April 29, 2020, from http://www.xinhuanet.com/english/2019-04/18/c_137988292.htm.

Yeo, G. T., Ng, A. K., Lee, P. T. W., \& Yang, Z. (2014). Modelling port choice in an uncertain environment. Maritime Policy \& Management, 41(3), 251-267.

Yu, H. (2017). Motivation behind China's 'One Belt, One Road'initiatives and establishment of the Asian infrastructure investment bank. Journal of Contemporary China, 26(105), 353-368.

Yuen, K. F., Thai, V. V., \& Wong, Y. D. (2017). Corporate social responsibility and classical competitive strategies of maritime transport firms: A contingency-fit perspective. Transportation Research Part A: Policy and Practice, 98, 1-13.

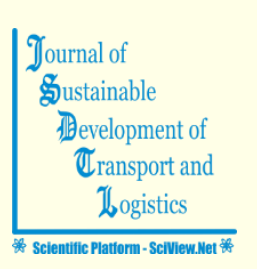

() 2016-2020, Journal of Sustainable Development of Transport and Logistics. All rights reserved. This open access article is distributed under a Creative Commons Attribution (CC-BY) 4.0 license.

You are free to:

Share - copy and redistribute the material in any medium or format Adapt - remix, transform, and build upon the material for any purpose, even commercially.

The licensor cannot revoke these freedoms as long as you follow the license terms.

Under the following terms:

Attribution - You must give appropriate credit, provide a link to the license, and indicate if changes were made.

You may do so in any reasonable manner, but not in any way that suggests the licensor endorses you or your use.

No additional restrictions

You may not apply legal terms or technological measures that legally restrict others from doing anything the license permits.

Journal of Sustainable Development of Transport and Logistics (ISSN: 2520-2979) is published by Scientific Publishing House "CSR", Poland,

EU and Scientific Publishing House "SciView", Poland, EU

Publishing with JSDTL ensures:

- Immediate, universal access to your article on publication

- High visibility and discoverability via the JSDTL website

- Rapid publication

- Guaranteed legacy preservation of your article

- Discounts and waivers for authors in developing regions

Submit your manuscript to a JSDTL at https://jsdtl.sciview.net/ or submit.jsdtl@sciview.net 